\author{
Nguyen Thanh $\mathrm{Nam}^{\star}$ \\ Hanoi University of Culture, Hanoi, Vietnam \\ https://orcid.org/0000-0003-4732-809X

\section{Ethnic minority community access to popular culture in the context of tourism (case of Thai ethnic group in Lac Village, Mai Chau, Hoa Binh, Vietnam)}

\title{
Introduction
}

Vietnam is one of the developing countries which is following the trend of industrialization and modernization. The process of economic and cultural globalization makes Vietnam face inevitable conflicts that other countries also often encounter. In localities with tourism activities, along with the development of the tourism economy, it is a matter of receiving new cultural trends and phenomena and, at the same time, modernizing traditional culture, but also leading to the risk of losing cultural identity. Facing such a situation, finding a suitable and effective solution in the way of balancing between receiving new culture and preserving cultural identity is a really necessary job.

In a survey conducted by lecturers and students of the Faculty of Cultural Studies at Hanoi University of Culture in October 2019 on the culture of the Thai ${ }^{1}$ ethnic group in Lac Village ${ }^{2}$, Mai Chau district, Hoa Binh province (a mountainous province in the North of Vietnam), the author has experienced and interacted with individuals, indigenous communities and local management officials. Participating in the local community tourism model, as indicated by interviews with indigenous peoples, many people thought that the traditional Thai culture of the local people had changed in addition to receiving a lot of current events. On a scientific level, this is a phenomenon that is reflected in many international studies on the culture of the local community being put into tourism, becoming a tourism product that will often be commercialized (commoditization) (Greenwood, 1977; MacCannell, 1973), and since then lost its own identity. Most of these studies have focused on the perception of travelers about 'honesty' or from the 'before and after' perspective when the host culture becomes a travelling destination. In the current context of tourism development, the local community has, in a different

\footnotetext{
1 Thai (Thái) is the name of an ethnic minority living in the North of Vietnam.

${ }^{2} \mathrm{Lac}(L a ́ c)$ is the name of the village in Mai Chau district, Hoa Binh province, Vietnam.
}

\footnotetext{
* Correspondence address: No 418, La Thanh street, Hanoi, Vietnam, e-mail: thanhnamdhvh@gmail.com.
} 
perspective, been proactive in receiving popular cultural phenomena in order to modernize the traditional culture of the ethnic groups in their own way.

\section{The receipt of popular culture}

\section{by ethnic minority communities in the tourism context}

Community is a broad-content concept with many different meanings, so the it has become the object of many scientific domains such as economics, tourism, health care, education and arts. In social sciences, the area of interest in researching the community is the field of sociology which does not study the community in general but the social communities. The social communities that are subject to the study of sociology vary from tightly organized social entities to less organized organizations like the mass movement, public audience, crowd. Sociologists consider a social community to consist of members as individuals, that is, a community of individuals determined by the community of interests or conditions. According to Hop T.D, "community is a social entity with an organizational structure (coherent or not), a group of people who share and are bound by characteristics and common interests, established through interaction and exchange between members" (Hop, Quang, 2000).There are many types of communities that exist in one nation. In a multi-ethnic country like Vietnam, each ethnic group is a community, in which ethnic minority communities are groups of people in small numbers, who share the same production methods, languages and culture and self-consciousness of belonging to that group.

The concept of popular culture emerged in the 1960s. Sociologists have mainly emphasized the mode of production of this culture according to the scheme of mass industrial production; especially the popularity of the mass media leads to cultural identity. The mass media have grown in line with the introduction of productivity and profitability standards related to cultural production. 'Manufactured' tends to replace 'creative' culture. Mass media are considered to entail cultural alienation, destroying every individual's ability to create culture, since there is no way to avoid the influence of the media. In fact, popular cultural products are goods made for consumption to satisfy the entertainment needs of consumer society. Therefore, popular culture contains a tendency to simplify the problem of leaving out the specific angles of each particular cultural stream. Popular culture is simply culture that is widely favoured or well-liked by many people (Storey, 2009). The development of the current creative industry helps the entertainment needs of the public be easily and readily satisfied through the consumption of popular cultural products.

Tourism is now regarded as an industry operating on the model and principles of industrial production, which emphasizes the production according to the needs of the 
market. In essence, the art of traveling temporarily takes visitors away from their culture and locality to a different cultural environment in a nearby city or a village half a world away. But tourism is supposed to provide something more or different for both the visitors and the host community welcoming visitors (McKercher, du Cros, 2002). Community involvement is one of the important philosophies of tourism development. This philosophy recognizes that in order for a community to develop well and sustainably, there must be effective consensus and coordination of all social forces and social institutions. People's participation is mainly related to the economy and politics in a wide range of society; it is not only an involvement in tourism programmes and projects, but also a process enabling local people to organize their own tourism through their own organization, to identify their needs, share designs, implement and evaluate the actions involved. Community participation in tourism means that the people at tourist destinations together with the state and socio-economic organizations carry out tourism activities to help the local tourism development, ensuring fair division of interests of stakeholders. Local communities are people who directly or indirectly do tourism, as they exploit the local human and natural resources to produce tourism products, they are the owners transforming local culture or preserving traditional culture, or receiving culture from outside, including cultural phenomena belonging to popular culture.

\section{Research method}

In order to know about tourism activities in Lac Village and cultural activities of the White Thai people and give an understanding of how the local community receives popular culture under the impact of tourism, the students of the Faculty of Cultural Studies at Hanoi University of Culture conducted an ethnographic fieldwork study in October 2019. We have directly experienced the 'three together' tourism model (eating, staying and working with the locals) at a White Thai homestay at Lac Village. We have observed and participated directly in making food with local Thai people, observed brocade weaving and attended folk art performances of the people to welcome tourists to the village. We have conducted interviews with local managers, village heads, homestay families, tram drivers, etc. We have made observations and talked with local tourists (both domestic and international visitors) about the products they buy locally, as well as the experience of the community services they have at Lac Village. The method of interviewing with different subjects will help the research to gain more comprehensive and insightful look. In addition, direct fieldwork is valuable in the field, meaning that the interviewer will not only hear, talk, but also feel from the person answering the question. The interviewer can clearly understand the attitude of the interviewee not only expressing their opinions verbally, but also through the facial expressions and gestures of the interviewee. 


\section{Introduction of the study area and the research ethnicity}

Lac Village is a village in Chieng Chau commune, Mai Chau district, Hoa Binh province. The village is located about $2 \mathrm{~km}$ from the center of Mai Chau district and $1.5 \mathrm{~km}$ from the center of Chieng Chau commune to the Northwest, near inter-district and inter-provincial roads, which is convenient for traveling and cultural and economic exchanges with the region vicinity. Lac Village has a total area of 429 ha, including 33.9 ha of cultivated land, of which the remaining 24.1 ha is agricultural land and other special-use land. Up to now, the whole village has more than 200 households, of which the Thai White ethnic group accounts for $98.89 \%$ and the rest is Kinh people (the majority of Vietnam) and Muong group. The Kinh and the Muong live in Lac Village with the status of bride and groom, namely there is a bride of the Muong, Thanh Hoa, a bride of the Muong, Kim Boi and a groom of the Kinh in Bac Ninh province.

According to the villagers, from the 1980s, Lac Village was chosen as weekend place for Russian workers building Hoa Binh hydroelectric plant. Along with Russian workers, there is a number of Frenchmen who have been serving in the army and stationed at Dong beach (a location near Lac Village) and were the first tourists to discover the beauty of the ecological landscape of this place. Tourism in Lac Village has been developing since around the 1980s, but it was only officially licensed by the provincial government in 1993. Although Lac Village had welcomed a lot of tourists before, it was only in 1994 that the district authorities set up a policy to build a tourist site before they could collect tourists' money. From only 2 families offering a place for guests to rest, now there are 43 households doing tourism. In the first days, the villagers did not know about tourism, they simply welcomed the guests. Like many other ethnic groups, Thai people are very hospitable. Mr. Thuong ${ }^{3}$ recalled:

When the first guests came to visit with my family, it was normal for us to welcome them. If we ate anything, we shared it with the customers. Later, because the customers' liked to learn about our family's daily life, we will introduce to the guests what we have. We can do it and give it to customers as a souvenir (Nam N.T. personal interview, October 10, 2019).

Coming to Lac Village, domestic tourists choose this place mainly to relax and enjoy food. Some families in Hanoi take their children to Lac Village, in addition to resting, to enjoy the fresh air, traditional dishes, but also for their children to understand the culture and life of the people in rural mountainous areas. For example, their children will have an interesting experience close to the mountains, the rice paddies, the haystacks, traditional houses and animals like cows, buffaloes, etc., which they cannot

3 Mr Thuong is a son of a family welcoming the first foreign tourists in Mai Chau. 
meet in urban areas. As for students, these are useful extracurricular lessons, which allow to accumulate a lot of experience to serve their learning. Foreign tourists are interested in learning about traditional culture through art performances, souvenirs, food.

Every year, Lac Village welcomes tourists from the second half of July of the previous year until the end of April next year, except for the hot months like May, June and the first half of July. By 2017, there were about 115,572 domestic tourists and about 48,264 foreign visitors visiting Mai Chau (Huyện Mai, 2017).

\section{Research content}

Lac Village, the home of the White Thai ethnic group in Mai Chau, Hoa Binh, is a popular tourist destination in Northwest Vietnam today. The research content of this article focuses on the issue of local residents' reception and use of cultural phenomena in the context of tourism activities quite vibrant in the locality today. The aim is to discuss issues such as the community that receives and uses the mass media, the community that receives mass cuisine, and the community that receives and implements the way of mass tourism.

\section{Community receives and uses mass media}

If communication is an act that predates the pre-human society and can happen without purpose, mass communication as a deliberate social process is a process of communicating widely to people in society through the mass media. In the $20^{\text {th }}$ century, with the development of radio, television, and telephone followed by the appearance of personal computers and then the global computer network and the Internet, the mass media developed greatly and had influence on individuals as well as on the whole society. Mass media are not only an institution that plays an important role in disseminating information and knowledge to the people, but also has a profound and powerful impact on all other social institutions from politics, economy to culture, society. Among many types of mass media appearing locally such as newspapers, radio, television, the type of community communication that is used the most often is the Internet. In 2005, the Internet became popular in Vietnam. The main users of the Internet are young people. It can be said that the Internet is the most effective means contributing to the spread of mass culture movements around the world. Thanks to the Internet, Vietnamese people easily receive popular cultural products from around the world. In Lac Village, Mai Chau, Hoa Binh, according to Mr. Ha Cong Tin - the head of a family who has had homestay business for more than 10 years, $95 \%$ of local households participating in tourism activities have access to the Internet. The television sets used at these households not only receive Vietnamese or local television channels, but also use Internet television. Online 
business channels such as Facebook, Zalo, Instagram, G + have been used by local youth to advertise their own family travel services. Mr. Long ${ }^{4}$, a local young man with a family that is doing business, said that:

Recognizing the benefits of advertising on social networks, I myself have found a way to learn and advertise my homestay on my Facebook and Youtube accounts. In the future, if possible, I will use the flycam to shoot sweeping scenes of the village space. I will create realistic and close scenes so that Lac Village will be more popular in the world (Nam N.T. personal interview, October 11, 2019).

\section{The community embraces a popular culinary culture}

In terms of cuisine, the local community has changed the structure of dishes in daily meals. Traditional dishes are not used much and are made only during Tet. Vietnamese dishes or Western dishes appear in the village popularly. When processing dishes for guests, the host always prepares dishes for the family to save time and money. The change in cuisine contributes to serving tourists more conveniently. Raw products for preparing Thai food in Mai Chau also have changed a lot. Most raw products are purchased in the market to serve the needs of tourists and the needs of the local people. Processing techniques have also changed a lot: food is mainly cooked, grilled, stored, boiled by electric stoves, gas. In the locality, there have been ready-made, canned and fast-food dishes available for immediate use. Various beverages such as bottled water, beers, wines, carbonated soft drinks, bottled fruit juices are imported from other places. Accommodation businesses have refrigerators for guests to keep drinks cold. At present, Thai people in Mai Chau do not make alcohol at all. Other chemicals in Vietnam as well as in the world are an integrated element of economy. Tourism development let people from the village experience the culture of tourists. Besides, in order to serve these visitors, instead of promoting the traditional cultural identity, the people here have adopted some types of popular culinary culture of other cultures.

\section{Community accesses and implements mass tourism}

Due to the local development of tourism, traditional Thai stilt houses have been newly built or renovated. Many stilt houses are no longer built with wooden columns; they are built with concrete. The main space of the stilt house is used to serve guests. Local accommodation service standards are implemented, hygiene is at the forefront and there is a regular inspection by the environmental agency. The local community has actively acquired the clean and tidy consciousness of international tourists, especially Western ones.

4 Mr Long is a local young man with a family that is doing tourism business in Lac village. 
Traditional weaving is present in almost all ethnic communities in Vietnam. In the context of weaving tourism of White Thai women in Lac Village, they have developed into craft villages and cooperatives. Specifically, in 2010, Chieng Chau commune established a traditional brocade weaving cooperative and Lac Village is one of the branches of that cooperative. The head of the branch is Ms. Di L.T. born in 1986 (formerly a seamstress), and the branch consists of 20 members, including a head, a deputy head, a cashier and an accountant. The brocade branch in Lac Village was not established due to the policy of the commune or district but is an initiative of local people, contributing capital and recruiting workers. The recruitment process is not too complicated because all Lac women know how to weave; girls are traditionally taught by mothers. Raw materials for weaving are not the same as before, but are imported from places like Yen Chau, Lai Chau. The way of dyeing also changed a lot, mainly dyeing products from Laos for Thai and wool blends. As to the weaving technique, the loom, the traditional weaving tool, has remained the same. Today, in order to achieve greater efficiency, Thai people in Lac Village have improved some parts of the process such as the tool to wrap the yarn into the core of the yarn, which has now been improved by using a wheel rim pedal, and the crank section is now fitted with a motor to spin faster and bring more efficiency. The development of local textile towards industry is due to the demand for products. The handicraft products that tourists often buy are souvenirs from brocade fabric such as towels, tablecloths, wrapping, seat cushions, bags.

Lac Village has 6 permanent performance teams and each team has 10-14 actors and actresses. In particular, every Saturday and Sunday night at the open ground by a campfire a musical performance begins when the bonfire is set. The dances were carefully prepared by the farmers, mainly praising the land and introducing the traditional Thai culture. At the end of the show, the performance visitors are welcomed to join in the dance around the fire with the jars of wine needed for the delight. Besides traditional music, also Western music (especially pop, dance) is performed according to the program to serve young tourists.

\section{Conclusions}

Lac Village is one of the cultural tourist sites in the Northwestern mountainous area of Vietnam which is quite typical example of the community that use and exploit the local traditional culture for tourism development. Tourism development is also a good environment not only to nurture and preserve ethnic culture, but also to absorb and integrate popular cultural values and phenomena from around the globe. With the development of tourism, the economic, cultural and social life of the White Thai community in Lac Village has been significantly improved. This change is associated with changes in livelihood activities of local people through the tourism development pro- 
cess. The change in economic structure with the emergence of many new livelihood activities shows the people's flexibility and quick adaptation to the tourism development context. The process of developing tourism activities of the White Thai community in Mai Chau has led to many cultural changes of the local people; this process has strong impact both in positive and negative way. With the development of tourism activities, the positive change in culture is reflected in the change in infrastructure systems, with clean and beautiful houses and costumes. The tradition is preserved and promoted, the people have gained more new types of culture, contributing to cultural diversity, as well as improving the quality of life of the people. However, besides the positive changes, there are some downsides of the change. It is the disappearance or doping in traditional culture, the loss of traditional ethnic cultural values. The tourism landscape with the development of the market economy also creates conflicts, disagreements between individuals and communities, between traditional and modern culture, between the popular cultural phenomena or the masses of humankind with specific traits in the culture of each ethnic group. However, the nature of these contradictions is the motivation to guide the local community how to have a better life in the imperative of changing their own community in the development of society.

\section{Bibliography}

Binh T.V. (2006), Cultural life of ethnic minorities in the process of industrialization and modernization, Hanoi.

Chi B.ui (2001), Folk cuisine of Muong Hoa Binh, Hanoi.

Chi N.T. (2015), Ethnic identity, cultural heritage and tourism: Case study of Muong and Thai people in Hoa Binh, Doctoral Thesis specialized in Folklore, Academy Social Science of Vietnam.

Chien N.T. (2004), Exploiting cultural heritage as a tourism resource, "Journal of Culture and Arts", No. (2), pp. 38-42.

Chinh L.C. (2004), Potential and promising Hoa Binh tourism, "Vietnam Tourism Magazine", No. (8), pp. 32-41.

Greenwood D.J. (1977), Culture by the Pound: An Anthropological Perspective on Tourism as Cultural Commoditization, [in:] Hosts and Guests, edit. V.L. Smith, Philadelphia, pp. 129-139.

Hall S. (1996), Modernity: An Introduction to Modern Societies, Massachusetts.

Hop T.D., Quang L.H. (2000), Community Development: Theory and application, Hanoi.

MacCannell D. (1976), The tourist: A New theory of the Leisure Class, New York.

McKercher B., du Cros H. (2002), Cultural Tourism - The Partnership Between Tourism and Cultural Heritage Management, New York.

Nga N.T.T. (2003), Weaving of Thai people in the Northwest in modern life, Hanoi.

Son T.H. (2003), Building a model of cultural tourism village, "Journal of Culture and Arts", No. (2), pp. 26-29.

Storey J. (2009), Cultural Theory and Popular Culture, Pearson Longman.

Huyện Mai Châu (Hòa Bình) đón trên 164 nghìn lượt khách du lịch trong 6 tháng đâu năm (2017), http://vietnamtourism.gov.vn/index.php/items/24159 [access on: 1.11.2019].

Nam N.T (2019, 10 and 11 October), personal interview. 
Abstract: Tourism is a growing service economic sector that creates jobs for many communities in the world. Ethnic minority communities in many countries are also now taking part in tourism activities. Vietnam is a country with great potentials for natural landscapes, historical values, indigenous culture of ethnic groups with habits and lifestyles, rich culinary culture of regions. It is the basis for development of tourism. Through tourism, tourists will understand the daily life of indigenous peoples, but at the same time people in these ethnic minority communities will have the opportunity to access popular cultural phenomena. This thesis discusses the ethnic minority communities' access to popular culture through tourism such as mass media, popular culinary culture or mass tourism. The case study was conducted in a village of ethnic minorities in Hoa Binh province, North Vietnam which has been undergoing changes under the impact of tourism in recent years.

Keywords: ethnic minority community, popular culture, tourism

Article submitted: 5.11.2019; article accepted: 30.11.2019. 